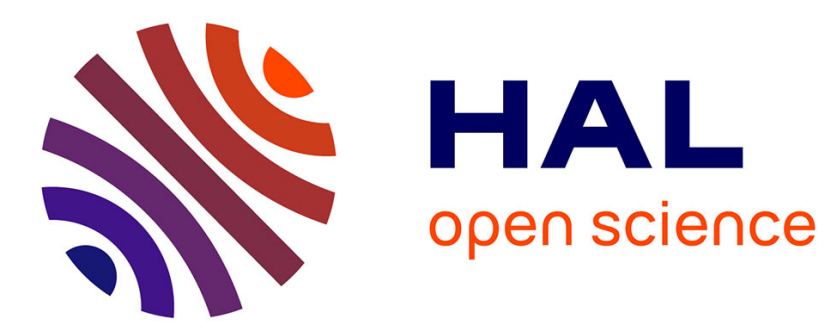

\title{
Correlation between self-ignition of a dust layer on a hot surface and in baskets in an oven
}

Agnès Janes, Douglas Carson, Antoinette Accorsi, Jacques Chaineaux, Benoît Tribouilloy, Daniel Moranviller

\section{> To cite this version:}

Agnès Janes, Douglas Carson, Antoinette Accorsi, Jacques Chaineaux, Benoît Tribouilloy, et al.. Correlation between self-ignition of a dust layer on a hot surface and in baskets in an oven. Journal of Hazardous Materials, 2008, 159 (2-3), pp.528-535. 10.1016/j.jhazmat.2008.02.057 . ineris-00961929

HAL Id: ineris-00961929

https://hal-ineris.archives-ouvertes.fr/ineris-00961929

Submitted on 20 Mar 2014

HAL is a multi-disciplinary open access archive for the deposit and dissemination of scientific research documents, whether they are published or not. The documents may come from teaching and research institutions in France or abroad, or from public or private research centers.
L'archive ouverte pluridisciplinaire HAL, est destinée au dépôt et à la diffusion de documents scientifiques de niveau recherche, publiés ou non, émanant des établissements d'enseignement et de recherche français ou étrangers, des laboratoires publics ou privés. 


\title{
Correlation between self-ignition of a dust layer on a hot surface and in baskets in an oven
}

Corresponding author:

A. JANES (INERIS - Parc ALATA BP 2 - 60550 Verneuil-en-Halatte - tel: + 33344 556142 - Fax: + 33344556200 - mail: agnes.janes@ineris.fr)

\section{Authors:}

\section{A. JANES - D. CARSON - A. ACCORSI - J. CHAINEAUX- B. TRIBOUILLOY - D. MORAINVILLERS}

\begin{abstract}
:
Evaluation of self-ignition hazard of bulk materials requires experimental determination of self-ignition temperatures as a function of volume. There are two standardised methods: (1) determination of the self-ignition temperature of dust samples in oven and (2) measurement of the self-ignition temperature of a dust layer deposited on a hot surface. Sometimes, the sample behaviour during these tests makes the second method difficult to apply.

The self-ignition phenomena in these two tests rely on the same principles. Their results are interpreted with the help of theoretical relations. The correlation described in this paper can be considered acceptable to deduce self-ignition temperature of a dust layer, based on results of self-ignition of the same dust in heating ovens, if the BIOT number ( $\alpha$ ) can be estimated. Uncertainty on the correlation is near $30 \mathrm{~K}$. This uncertainty is on the same order of magnitude as the difference in the self-ignition temperature on a hot surface for thickness between 5 and $15 \mathrm{~mm}$.
\end{abstract}

Key words:

Self-heating - Self-ignition temperature of a dust layer - Critical temperature FRANK-KAMENETSKII 


\section{Nomenclature:}
A: pre-exponential factor of Arrhenius equation $\left[\mathrm{s}^{-1}\right]$
$\mathrm{E}$ : apparent activation energy [J.mol $\left.{ }^{-1}\right]$
$\mathrm{h}$ : global heat transfer on storage surface (convection and radiation) [W. $\mathrm{m}^{-2} \cdot \mathrm{K}^{-1}$ ]
M: lumped parameter (which depends on parameters such as heat of combustion, heat capacity, density) [dimensionless]
$\mathrm{P}$ : lumped parameter $[\mathrm{K}]$
$r$ : critical dimension (half-edge length of cubic basket at the self-ignition temperature) $[\mathrm{m}]$
R: universal gas constant. 8.314 [J.(mol.K $\left.)^{-1}\right]$
$\mathrm{Q}$ : heat of reaction per unit mass $\left[\mathrm{KJ}^{\mathrm{kg}}{ }^{-1}\right]$
$\mathrm{T}_{\mathrm{a}}$ : room temperature $[\mathrm{K}]$
$\mathrm{T}_{\mathrm{c}}$ : self-ignition temperature of a given sample volume $[\mathrm{K}]$
$\mathrm{T}_{\mathrm{e}}$ : isothermal oven temperature $[\mathrm{K}]$
$\mathrm{T}_{\mathrm{p}}$ : hot plate temperature $[\mathrm{K}]$
$\mathrm{T}_{\mathrm{s}}$ : upper surface temperature $[\mathrm{K}]$
$\mathrm{T}_{0}$ : storage's central point temperature $[\mathrm{K}]$
z: critical dimension (half- thickness of the layer at the self-ignition temperature) [m]

\section{Greek symbols}

a: BIOT number [dimensionless]

$\delta_{c}$ : FRANK-KAMENETSKII parameter for heating oven tests. 2.6 for a cubic storage [dimensionless]

$\delta_{\mathrm{cp}}:$ FRANK-KAMENETSKII parameter for hot plate tests [dimensionless]
$\lambda$ : thermal conductivity of material $\left[\mathrm{W} \cdot \mathrm{m}^{-1} \cdot \mathrm{K}^{-1}\right]$
$\rho:$ density $\left[\mathrm{kg} \cdot \mathrm{m}^{-3}\right]$ 


\section{INTRODUCTION}

Self-ignition is a common source of ignition of porous storage of bulk materials such as powders and dusts. Evaluation of this ignition hazard, taking into account manufacturing or storage conditions, requires experimental determination of critical self-ignition temperatures as a function of volume.

One of the first standardized tests [1] consists of measuring the minimum temperature of a flat hot surface which results in the ignition of a dust layer of a given thickness, which is generally $5 \mathrm{~mm}$. This test is particularly relevant for industries where dust is handled and can accumulate on potentially hot surfaces. However, this test is not always easy to carry out when the dust is blown away due to air movement or when the layer cracks due to the hot surface. Thus, when testing a $5 \mathrm{~mm}$ layer is not possible, the same test can be carried out with a thicker dust layer. Consequently, as we know [2], the self-ignition temperature will be lower than that of a $5 \mathrm{~mm}$ layer. This vas more recently reported by EL SAYED [3].

A second test is used to determine critical self-ignition temperatures. Bulk materials are placed in several baskets of various sizes, which are placed in a heating oven. So far, according to a theoretical model, relation between self-ignition temperature and bulk storage size can be found. This second method is easier to conduct than the previous one. This second method is also used to classify self-ignition substances for the transport of dangerous goods [4]. This classifying methodology was discussed in the past [5] and [6].

Phenomena highlighted in these two tests are similar and their results can be connected with theoretical relations.

The aim of this paper is to describe a correlation model between both methods. Then, results of an experimental validation campaign are presented and discussed. 


\section{CONTEXT}

Since application of European directive 1999/92/EC [7], several actions must be taken by employers. It includes:

- evaluation of explosive atmospheres ${ }^{1}$ hazards,

- classification of area where explosive atmospheres may occur,

- identification of technical and/or organisational explosion control measures,

- use of appropriate electrical and non-electrical apparatuses according to area classification,

- set up and regular update of the so called "explosion protection document".

Explosion hazards assessment shall take into account the likelihood that ignition sources will be present and become active and effective. Thus, substances used and their ignition probability shall be considered to select safe work equipment and safe working conditions.

As far as electrical apparatuses are concerned, EN 1127-1 standard [8] sets two specifications for devices. One is about dust permeability and the other concerns limitation of surface temperature.

Indeed, this standard considers that apparatuses can be safely operated when dust is present, if its maximum surface temperature is:

- lower than the two thirds of dust self-ignition temperature in cloud, and

- lower than the self-ignition temperature of a $5 \mathrm{~mm}$ layer minus $75 \mathrm{~K}$.

So far, reliable methods are needed to determine self-ignition temperatures in order to demonstrate the safe use of equipment.

Standards applied in this study are:

- EN 50281-2-1 [1]: Electrical apparatus for use in the presence of combustible dust - Part 2-1: Test methods - Methods for determining the minimum ignition temperature of dust,

- PrEN 15188 [9]: Determination of the spontaneous ignition behaviour of dust accumulations.

\footnotetext{
${ }^{1}$ «Explosive atmosphere » means a mixture with air, under atmospheric conditions, of flammable substances in the form of gases, vapours, mists or dusts in which, after ignition has occurred, combustion spreads to the entire unburned mixture [4]
} 


\section{SELF-IGNITION MODELING}

Self-ignition is related to exothermic oxidation reactions within the mass of bulk particle storage.

When the storage conditions do not allow complete dissipation of heat generated by these slow going oxidation reactions by the means of a sufficient heat exchange between reactional system and external environment, a rise of temperature within the mass is observed.

Three parameters are predominant for self-ignition phenomenon:

- product temperature, in regard to ambient temperature,

- storage size,

- oxygen diffusion conditions through the storage.

Models of self-ignition were developed in the 1920's by SEMENOV. This work was then continued by FRANK-KAMENETSKII [10] and later by THOMAS [11].

A comparison of SEMENOV and FRANK-KAMENETSKII theories was recently proposed by Shouman [12].

SEMENOV's model considers an equal temperature throughout the volume, as shown on figure 1a. It is based on geometrical dimensions, surface and volume of storage. Since this model does not take into account heat gradients between centre and periphery, it is not valid for large size storage.

FRANK-KAMENETSKII's model takes into account a temperature gradient inside the sample, which depends on its geometrical dimensions and thermal conductivity. In this model, heat transfer is achieved by optimal conduction into the material, and by convection and radiation on the storage periphery. In this case, as shown on figure $1 \mathrm{~b}$, surface temperature is equal to ambient temperature.

This last hypothesis implies a high and global coefficient of heat transfer on the storage surface. If not, the surface temperature remains higher than ambient temperature.

Finally, THOMAS and BOWES'model [2] takes into account both internal thermal resistances by conduction and external thermal resistance by convection and radiation. This theory considers thermal conductivity of material, geometrical dimensions of storage as well as parameters of convection and radiation at the interface between material and air. The relation between thermal conduction inside the storage and convection on the surface is given by equation 1 [2], which uses the BIOT number ( $\alpha)$. 


$$
\alpha=(h . r) / \lambda
$$

BIOT number depends on storage size. It tends towards 0 when storage size tends towards 0 for equal values of global heat transfer coefficient on storage surface and thermal conductivity inside the sample.

When thermal conductivity of material is high compared to exchange coefficient on surface, BIOT number tends also towards 0 . In this case, internal temperature of sample is homogeneous and higher than ambient temperature, that correspond to SEMENOV's theory.

On the contrary, if thermal conductivity of material is low compared to heat transfer on surface, BIOT number tends towards infinite, that corresponds to FRANKKAMENETSKII's model.

If there is an equal repartition of heat transfer resistance between inside storage conduction and outside convection and radiation, BIOT number is equal to 1 .

\section{CORRELATION BETWEEN SELF-IGNITION OF A DUST LAYER} AND SELF-IGNITION IN AN OVEN

Critical self-ignition temperature is determined for different sizes of cubic latticed baskets in isothermal ovens, which are filled by samples, as it is described in $\operatorname{Pr}$ EN 15188 standard [9]. Experimental results take the form of couples of data $\left(r, T_{c}\right)$ where $r$ is the half-edge length of cubic basket and $T_{c}$ the critical self-ignition temperature, for each sample.

These values are introduced in the model written as shows equation 2 [2].

$$
\operatorname{Ln}\left[\left(\delta_{\mathrm{c}} \cdot \mathrm{T}_{\mathrm{c}}{ }^{2}\right) / \mathrm{r}^{2}\right]=\mathrm{M}-\left(\mathrm{P} / \mathrm{T}_{\mathrm{c}}\right)
$$

where

$M=\operatorname{Ln}[(E . Q . \rho . A) /(R . \lambda)]$

$P=E / R$

Notes:

$\mathrm{Ln}$ is the Napierian logarithm

$M$ and $P$ parameters can be calculated by linear regression (least square method).

To make the equations (2) and (3) be rigorous, it is necessary to add a multiplication coefficient equal to $1\left[\mathrm{~K}^{-2} \mathrm{~m}^{2}\right]$ in the expression $\left(\delta_{\mathrm{c}} \cdot \mathrm{T}_{\mathrm{c}}{ }^{2}\right) / \mathrm{r}^{2}$. 
In the particular case of a layer deposited on a hot surface, ambient temperature is not homogeneous and the heating is unsymmetrical.

The temperature of the layer in contact with the hot surface is equal to hot surface temperature itself, while the external layer surface temperature can be calculated with ambient temperature and BIOT number, according to equations 3 and 4 [2].

$$
\operatorname{Ln}\left[\left(\delta_{c p} \cdot T_{c}^{2}\right) / r^{2}\right]=M-\left(P / T_{c}\right)
$$

$\delta_{\mathrm{cp}}$ is calculated according to equation 5 below.

$$
\delta_{c p} \approx \frac{1}{2}\left(\frac{\alpha}{1+2 \alpha}\right)^{2}\left(1.4+\frac{E}{R T_{p}^{2}} \boldsymbol{\gamma}_{p}-T_{a}\right)^{2}
$$

The validity conditions of equation 4 are [2]:

- $\left(\mathrm{E} / \mathrm{RTp}^{2}\right) \cdot(\mathrm{Tp}-\mathrm{Ta})>8$, and

- $\alpha>0.5$.

In the case of self-ignition by a hot surface, the geometrical constant depends on several parameters, such as apparent activation energy $(E)$, ambient temperature $\left(T_{a}\right)$, hot surface temperature $\left(T_{p}\right)$ and geometry of the deposit and efficiency of heat transfer between hot surface and dust layer. On the contrary, in the case of selfignition in an isothermal oven, the geometrical constant depends only on geometry of the basket.

By dividing equation 4 by equation 2, for the condition $\mathrm{T}_{\mathrm{e}}$ (determination of selfignition temperature by isothermal oven method) $=T_{p}$ (determination of self-ignition temperature by hot surface method), equation 5 is obtained.

$$
\frac{z}{r}=\frac{\sqrt{\delta_{c p}}}{\sqrt{\delta_{c}}}
$$

Development of equation 5 leads to equation 5 '. 


$$
r=\frac{2.28 z}{\left(\frac{\alpha}{1+2 \alpha}\right)\left(1.4+\frac{E}{R T_{p}{ }^{2}} \boldsymbol{\sigma}_{p}-T_{a}\right)}
$$

Equation 5' gives the half-size of a cube tested in isothermal oven, which corresponds to the half-thickness of a layer deposited on a hot surface for which the self-ignition temperature is equal to the self- ignition temperature of the cube.

Prediction of the critical temperature of a dust layer deposited on a hot surface can be done by plotting this equation 5' on a graph. The intersection point with the curve obtained by isothermal oven test, for the same sample, gives the theoretical selfignition temperature of a layer on a hot surface.

\section{APPARATUS AND PROCEDURE}

\subsection{IGNITION OF A DUST LAYER DEPOSITED ON A SURFACE HEATED AT A CONSTANT TEMPERATURE}

The minimum ignition temperature of a dust layer of specified thickness is the lowest temperature of a hot surface at which ignition occurs. According to EN 50281-2-1 [1] standard, determination of this temperature needs a heating electric resistance, with a metallic plate disposed on it. The maximum temperature of the plate used in this study is $450^{\circ} \mathrm{C}$.

Dust layer is prepared by filling the cavity formed by a metal ring of appropriate height, placed on the heated surface and by levelling the layer on the top of the ring. This ring, which internal diameter is equal to $100 \mathrm{~mm}$, is left in place during the test.

A given dust is tested in a layer of $5.0 \mathrm{~mm}+/-0.1 \mathrm{~mm}$ depth. Two other depths are also studied: $12.5 \mathrm{~mm}+/-0.1 \mathrm{~mm}$ and $15.0 \mathrm{~mm}+/-0.1 \mathrm{~mm}$.

Several temperature measurements are carried out during a test (fig. 2):

- ambient temperature, with a thermocouple ${ }^{2}$ placed at $1 \mathrm{~m}$ of the heated surface but shielded from heat convection and radiation from the surface,

- dust layer temperature, with a thermocouple stretched across the heated surface, parallel to it, $2 \mathrm{~mm}$ height from it, with the hot junction over the centre of the plate, 
- heated surface temperature, with a thermocouple disposed inside the heated plate mass, parallel to it and with the hot junction on the centre of the plate.

The dust is put into the ring with a spatula and spread without compressing.

For the determination of the minimum ignition temperature of a layer of a given thickness, repeated trials are carried out, using a fresh layer of dust for each trial and with up-and-down adjustments to the temperature of the heated surface.

Ignition is considered to have occurred if:

- visible glowing or flaming is observed, or

- a temperature of $450{ }^{\circ} \mathrm{C}$ is reached, or

- a temperature rise of $250 \mathrm{~K}$ above the temperature of the heated plate is measured.

Figure 3 shows ignition of a $5 \mathrm{~mm}$ zinc dust on the heating surface.

On the contrary, if none of these three conditions is satisfied after a 30 min delay, ignition is not considered to have occurred. This non-ignition test is repeated two times.

Trials are made until the ignition temperature is framed by a temperature value for which ignition is observed and another for which no ignition has occurred. These two values must not be different by more than $10 \mathrm{~K}$. The experimental ignition temperature of the dust layer is the lowest temperature.

We consider that these apparatus and procedure lead to an uncertainty of $+4.5 \mathrm{~K} /$ $14.5 \mathrm{~K}[13]$.

\subsection{SELF-IGNITION OF DUST IN OVENS}

Critical self-ignition temperatures for different size of cubic baskets are determined by successive trials in heating ovens.

According to the FRANK-KAMENETSKII's model, relation between self-ignition temperature and storage size can be set. Then, extrapolation from this relation can help, for different storage geometry to evaluate:

- the critical size (maximum size) of a storage for a specified temperature, which is particularly useful for low temperatures,

\footnotetext{
${ }^{2}$ all temperature measurements in this study use chromel-alumel $(K)$ thermocouples
} 
- the critical storage temperature (maximum temperature) for specified size and geometry.

According to PrEn 15188 [9], critical self-ignition temperatures are assessed using $125 \mathrm{~L}$ re-circulating air ovens, with a maximum temperature of $300^{\circ} \mathrm{C}$ and equipped with a middle-height grid, as shown on figure 4 . Ventilation is provided to exhaust any gases released from the dust.

The dust sample is filled into mesh wire baskets of different sizes with a spatula, without compressing and levelled on the top. Baskets are open at the top and closed at the bottom. The width of the mesh used, made of stainless steel, is equal to $10 \mu \mathrm{m}$, in order to avoid sifting but to allow oxygen diffusion. Volumes used in this study are: $8 \mathrm{~cm}^{3}, 125 \mathrm{~cm}^{3}, 343 \mathrm{~cm}^{3}$ and $1000 \mathrm{~cm}^{3}$, so critical sizes of cubic baskets (half height) are: $1 \mathrm{~cm}, 2.5 \mathrm{~cm}, 3.5 \mathrm{~cm}$ and finally $5 \mathrm{~cm}$.

These baskets, being filled by the sample, are located on the centre of the oven preheated to the test temperature.

Two temperature measurements are made during a test (fig. 5):

- oven temperature, with a thermocouple freely installed in the air space at half distance between the sample surface and the inner wall of the oven. Tests have shown that maximum temperature difference between two points in an oven is about $2 \mathrm{~K}$ [13],

- sample temperature, with a thermocouple located with its hot junction directly at the centre of the sample.

If sample temperature, after an induction delay, grows abruptly and rises at least $60 \mathrm{~K}$ above the oven temperature, it is considered that self-ignition is occurring. On the contrary, we assume that self-ignition did not occur if sample temperature is remains close to oven temperature after an induction delay or exceed it of a few $\mathrm{K}$.

A sufficient number of tests is carried out with a fresh dust sample for each trial, until the oven temperature is high enough to cause ignition of the sample but which is no more than $5 \mathrm{~K}$ higher than a temperature which fails to cause ignition. 
Critical temperature, for a specified basket size, is equal to the middle value of the interval framed by these two previous temperatures. We consider that the undertaking of the procedure described lead to an uncertainty of $+/-8.0 \mathrm{~K}$ [13].

When critical temperatures are obtained for the four baskets sizes, these experimental points can be correlated. For each of the four couple of data $\left(r, T_{c}\right)$ obtained, two coefficients (A, B) are calculated, according to equations 6 and 7 below.

$$
\begin{gathered}
A=\operatorname{Ln}\left(2.6 T_{c}^{2} / r^{2}\right) \\
B=1 / T_{c}
\end{gathered}
$$

Notes:

$\mathrm{Ln}$ is the Naperian logarithm

2.6 is the value of the Franck-Kamenetskii parameter for a cubic storage $\left(\delta_{c}\right)$.

According to the previous equation 2 (see also section 4) below [2], the plot of the four points $(A, B)$ describes a line.

$$
\operatorname{Ln}\left[\left(\delta_{\mathrm{c}} \cdot T_{\mathrm{c}}{ }^{2}\right) / \mathrm{r}^{2}\right]=\mathrm{M}-\left(\mathrm{P} / \mathrm{T}_{\mathrm{c}}\right)
$$

$M$ and $P$ parameters are then calculated by linear regression (least square method). 


\section{PROTOCOL SELECTED FOR EXPERIMENTAL CORRELATION}

In order to check experimentally the correlation between the results of self-ignition in ovens and self-ignition on heated surfaces, we proceeded as follow, for each of the 14 samples tested.

1. self-ignition tests in heating ovens, for the four sizes of cubic baskets and calculation of $\mathrm{M}$ and $\mathrm{P}$ parameters by correlation of experimental results,

2. calculation of geometrical constant $\left(\delta_{\mathrm{cp}}\right)$ and self-ignition temperature of dust layers by graphical determination, for three different layer thickness $(5 \mathrm{~mm}$, $12.5 \mathrm{~mm}$ and $15 \mathrm{~mm}$ ) and three different values of BIOT number (infinite, 1 and $1 / 2)$,

3. experimental determination of self-ignition temperature of dust layers, for the three different layer thickness $(5 \mathrm{~mm}, 12.5 \mathrm{~mm}$ and $15 \mathrm{~mm}$ ) of each sample,

4. comparison of experimental and theoretical results, for the three values of BIOT number.

We worked with three values of BIOT number, as follows:

- $\alpha$ = infinite (heat transfers limited by conduction): conditions of FRANKKAMENETSKII's model,

- $\alpha=1$ (heat transfers limited by conduction and convection): conditions of THOMAS and BOWES' model,

- $\alpha=1 / 2$ : theoretical limit of THOMAS and BOWES' model.

\section{RESULTS AND DISCUSSION}

Results of self-ignition tests in heating ovens are shown in table 1. Tables 2 to 5 show differences between experimental and theoretical results of self-ignition temperatures of dust layers. 


\subsection{INFLUENCE OF BIOT NUMBER ( $\alpha$ ) ON THEORETICAL SELF-IGNITION TEMPERATURES}

Comparison of theoretical values is shown on table 5. It shows that, for a given dust layer thickness, the calculated self-ignition temperature increases with $\alpha$ value. Table 5 points out that the difference between theoretical values of self-ignition temperatures is influenced either by dust layer thickness or by the nature of the sample. One exception is noticed: in the case of the activated carbon dust, the variation is significantly higher when a value is modified. This could be explained by the high value of carbon dust specific surface, in comparison with the others. This influences the value of the $\mathrm{M}$ and $\mathrm{P}$ global parameters when calculating theoretical self-ignition temperatures.

\subsection{DifFERENCE BETWEen EXPERIMENTAL AND THEORETICAL SELF- IGNITION TEMPERATURES}

Differences between experimental and theoretical self-ignition temperatures are shown in tables 2 to 4 . Accuracy of correlation obtained is illustrated on these tables by colouring: the darker, the less accurate correlation.

In a general basis, experimental results for $5 \mathrm{~mm}$ dust layers agree with theoretical previsions, excepted for two varieties of wheat dust ( $n^{\circ} 1$ and 3 ) and for the zinc powder. Calculated self-ignition temperatures are higher than experimental values for two thirds of the tested samples. The best correlation (difference lower than $10 \mathrm{~K}$ ) are obtained with a a value equal to 1 (5 cases out of 11 ).

Theoretical prevision under-estimates the experimental self-ignition temperature of $12.5 \mathrm{~mm}$ dust layers for every samples tested. Temperature differences are systematically higher are than $10 \mathrm{~K}$. The closest calculated temperature to the experimental one is obtained when a value tends to infinite. The worse correlation is obtained for one variety of wheat dust $\left(n^{\circ} 2\right)$.

Calculated self-ignition temperatures for $15 \mathrm{~mm}$ layers are lower than experimental values for $80 \%$ of tested samples. The best correlation (difference lower than $10 \mathrm{~K}$ ) are obtained when a value tends to infinite ( 3 cases of 7 ). The worse correlation is obtained for the coal dust. 


\subsection{SYNTHESIS}

Principal lessons resulting from this study are summarised below.

For $5 \mathrm{~mm}$ dust layers, it is possible to determinate a theoretical self-ignition temperature based on self-ignition tests in heating ovens. The most adapted BIOT number $(\alpha)$ seems equal to 1 , it corresponds to a repartition of heat transfer between conduction inside the layer and convection on the surface (THOMAS and BOWES's model). In these conditions, the uncertainty obtained for self-ignition temperature is less than $30 \mathrm{~K}$, except zinc powder $(150 \mathrm{~K})$ and wheat dust $\mathrm{n}^{\circ} 1(80 \mathrm{~K})$. It must be pointed out that calculated values are generally higher than experimental ones.

For $12.5 \mathrm{~mm}$ and $15 \mathrm{~mm}$ dust layer thickness, determination of a theoretical selfignition temperature based on self-ignition tests in heating ovens is also possible, if the chosen BIOT number $(\alpha)$ tends to infinite. This condition corresponds to the limitation of heat transfer by conduction inside the dust layer (FRANKKANENETSKII's model). For these conditions, the uncertainty on self-ignition temperature is about 10 to $30 \mathrm{~K}$, except for wheat dust $\mathrm{n}^{\circ} 2(98 \mathrm{~K})$ and coal dust (70 K).

This study has also shown that for several tested samples (e.g. zinc, wheat or coal dust), there is a discrepancy between theoretical value of self-ignition temperature and the experimental ones. Different explanations can be found:

- the most adapted $\alpha$ value can be lower than $1 / 2$. This is probably true for zinc dust. In fact, a study carried out by INERIS [13] showed that FRANKKAMENETSKIIs' model is not applicable to aluminum dust, due to good conduction efficiency. A complementary study is necessary to extend this hypothesis to other samples characterised by a high conduction coefficient, such as metal powders in specific granulometry conditions,

- samples chemical modification at low temperature, such as complex agroalimentary molecules. This could explain the poor correlation obtained for e.g. wheat dust,

- in the case of persulphate powder, a foaming was observed. This particular behaviour can also be one of the causes of a bad correlation.

In all these hypothesis, equations from FRANK-KAMENETSKII's model, which was used in the study, are not valid. 


\section{CONCLUSION}

The correlation method describes in this paper can be considered valid to estimate self-ignition temperature of a dust layer for several samples from the results of selfignition tests in ovens, if the value of BIOT number $(\alpha)$ is judiciously chosen:

- for $5 \mathrm{~mm}$ dust layers, the most adapted value is equal to 1 ,

- for $12.5 \mathrm{~mm}$ and $15 \mathrm{~mm}$ dust layers, it is preferable to choose a very high value for $\alpha$.

Uncertainty on results is lower than $30 \%$, if temperature is calculated in $\mathrm{K}$. It is in the same order than uncertainty induced by testing a $15 \mathrm{~mm}$ layer self-ignition temperature, which is less difficult to obtain but pessimistic, instead of a $5 \mathrm{~mm}$ layer self-ignition temperature.

Finally, when the sample behaviour (foaming...) does not allow to carry out the standardised procedure to measure self-ignition temperature of a $5 \mathrm{~mm}$ dust layer, we recommend:

- to calculate the theoretical self-ignition temperature based on results of selfignition tests in heating ovens, within the validity domain of FRANKKAMENETSKII's model,

- to consider the self-ignition temperature of a $15 \mathrm{~mm}$ thick sample, determined by the standardised method, in other situations.

In both cases, uncertainties on results must be taken into account.

Additional tests would help refine the knowledge of samples for which FRANKKAMENETSKII's model is not valid, e.g. materials whose conduction coefficient is very high or samples which undergo chemical conversion at low temperatures.

\section{AKNOWLEDGMENTS}

This work was financially supported by the French Ministry of Environment and Sustainable Development.

\section{REFERENCES}

[1] CEN, Electrical apparatus for use in the presence of combustible dust - Part 2-1: Test methods - Methods for determining the minimum ignition temperature of dust, European Standard EN 50281-2-1, European Committee for Standardization, Brussels, 2000 
[2] Bowes P.C., Self heating : evaluating and controlling the hazards, Elsevier, 1984

[3] El-Sayed S.A. and Abdel-Latif A.M., Smoldering combustion on dust layer on hot surface, J. Loss Prevent. Proc., 13 (2000) 509-517

[4] United Nation Organisation, Transport of Dangerous goods, Manual of Tests and Criteria, ref.: ST/SG/AC.10/11/Rev.4, 2003

[5] Chervin S. and Bodman G.T., Testing strategy for classifying self-ignition substances for transport of dangerous goods, Journal of Hazardous Materials, 115 (2004) 107-110

[6] Jones J.C., A new and more reliable test for the propensity of coals and carbons to spontaneous heating, J. Loss Prevent. Proc., 13 (2000) 69-71

[7] EU, European directive 1999/92/EC of 16 December 1999 on minimum requirements for improving the safety and health protection of workers potentially at risks from explosive atmospheres $\left(15^{\text {th }}\right.$ individual Directive within the meaning of Article 16 of Directive 89/391/EEC, 1999

[8] CEN, Explosive atmospheres - Explosion prevention and protection - Part 1: Basic concepts and methodology, European Standard EN 1127-1, European Committee for Standardization, Brussels, 1997

[9] CEN, Determination of the spontaneous ignition behaviour of dust accumulations, European project of standard PrEN 15188, European Committee for Standardization, Brussels, 2006

[10] Franck-Kamenetskii D. A., Diffusion and heat transfer in chemical kinetics, $2^{\text {nd }}$ edition, translated by J. P. Appelton, 1969, Plenum Press

[11] Thomas P. H., Ignition, heat release and non-combustibility of materials ASTM STP 502, American Society of Testing and Materials, 1972

[12] Shouman A.R., A review of one aspect of the thermal-explosion theory, J. Eng. Mat., 56 (2006) 179-184

[13] Janes A., Application de la norme EN 15188 relative à l'auto-échauffement des solides, Rapport d'étude pour le Ministère de l'Ecologie et du Développement Durable, Programme EAT-DRA36, Opérations 2 et 4, 2006 
Tables and figures

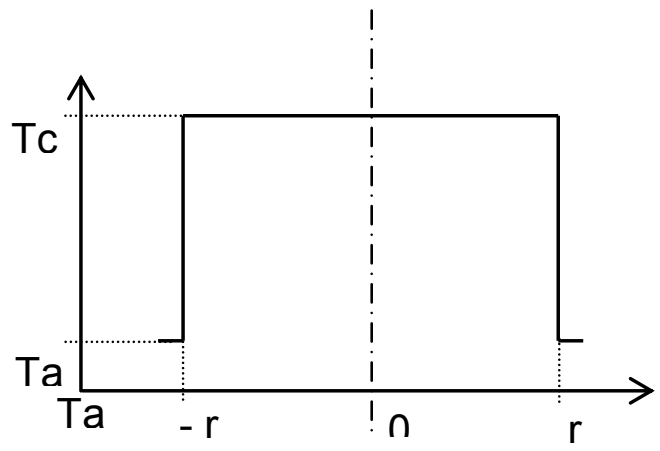

(a)

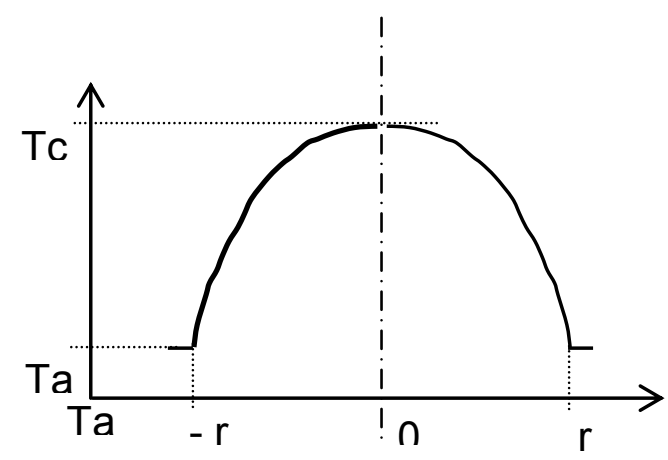

(b

Figure 1: Allure of theoretical temperatures in SEMENOV (a) and FRANKKAMENETSKII (b) models.

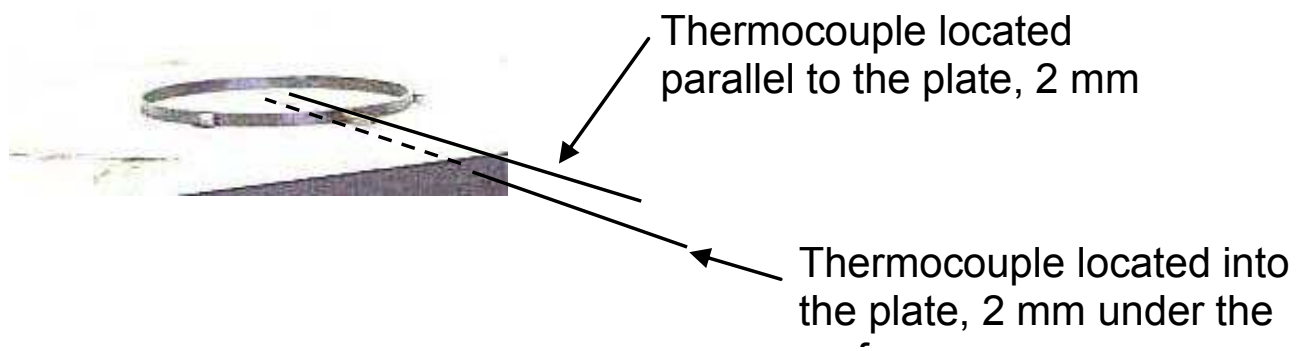

Figure 2 : Schematic view of the location of thermocouples while self-ignition tests on hot surface 


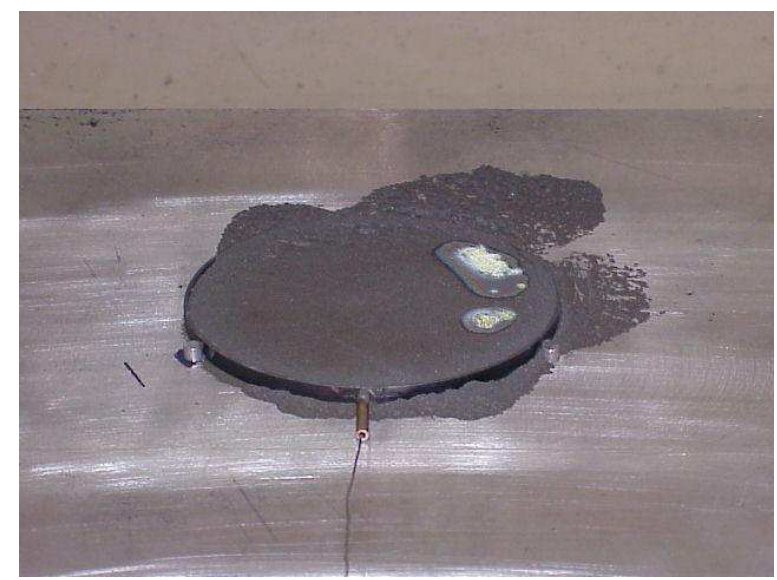

Figure 3: View of the ignition of a $5 \mathrm{~mm}$ metallic dust layer during a self-ignition test.

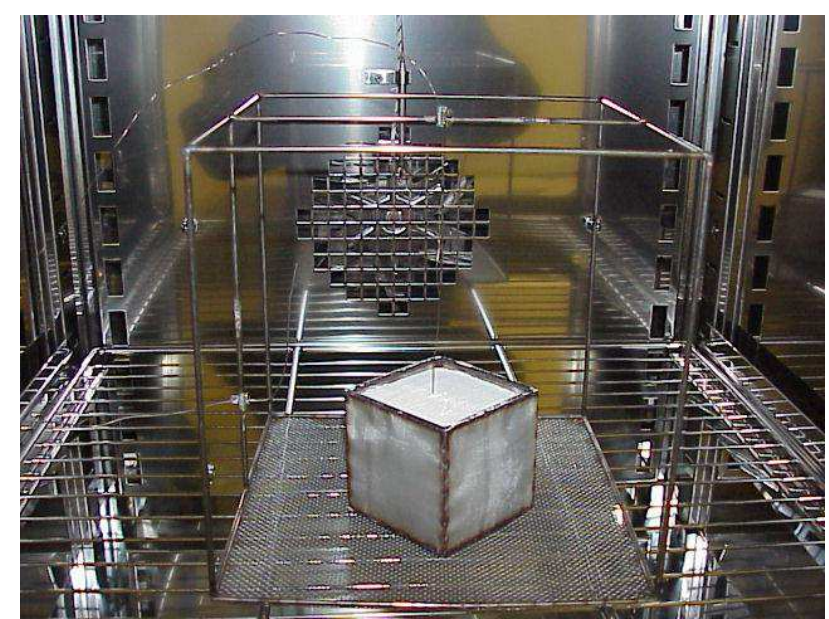

Figure 4: View of a filled basket inside a heating oven.

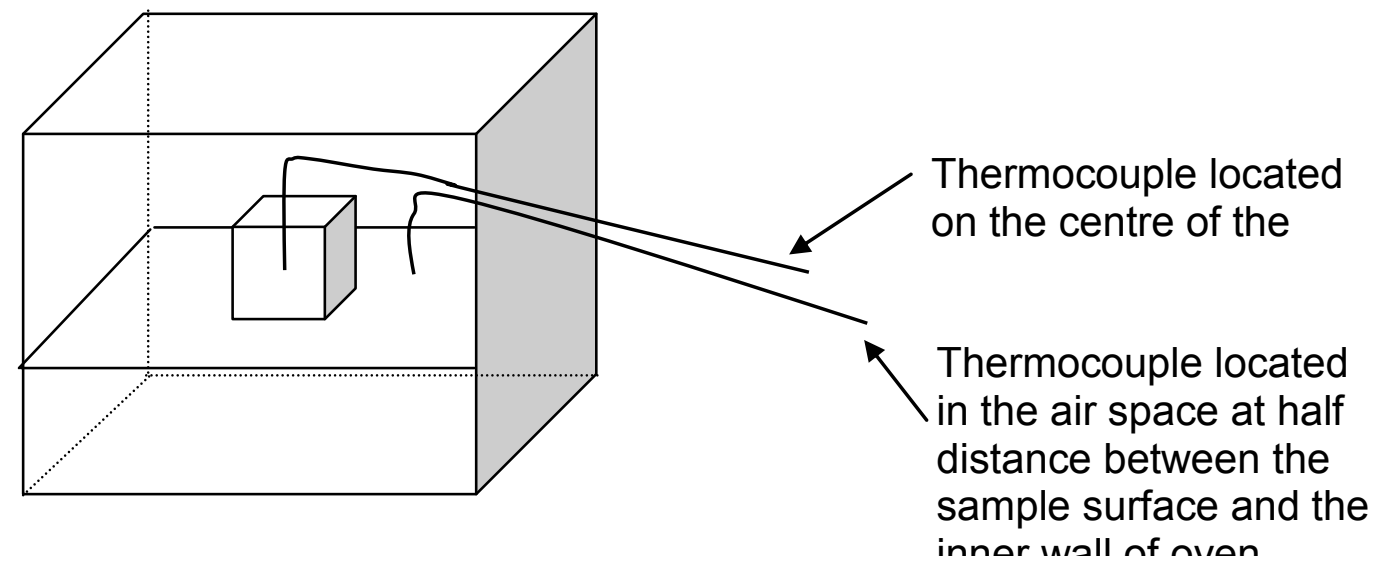

Figure 5: Schematic view of the location of thermocouples while self-ignition tests in ovens 


\begin{tabular}{|c|l|c|c|c|c|}
\hline \multirow{2}{*}{ Ref. } & \multicolumn{1}{|c|}{ Samples } & \multicolumn{4}{|c|}{ Self-ignition temperatures in heating ovens (in } \\
\cline { 2 - 6 } & $\begin{array}{c}8 \mathrm{~cm}^{3} \\
\text { cubic } \\
\text { basket }\end{array}$ & $\begin{array}{c}125 \mathrm{~cm}^{3} \\
\text { cubic } \\
\text { basket }\end{array}$ & $\begin{array}{c}343 \mathrm{~cm}^{3} \\
\text { cubic } \\
\text { basket }\end{array}$ & $\begin{array}{c}1000 \mathrm{~cm}^{3} \\
\text { cubic } \\
\text { basket }\end{array}$ \\
\hline 1 & $\begin{array}{l}\text { Purifying station mud } \\
\text { dust }\end{array}$ & 187 & 147 & 137 & 127 \\
\hline 2 & Wheat dust $\mathrm{n}^{\circ} 1$ & 222 & 187 & 147 & 142 \\
\hline 3 & Potatoes powder & 202 & 172 & 167 & 157 \\
\hline 4 & Crushed waste dust & 202 & 177 & 167 & 157 \\
\hline 5 & Zinc powder & $>300$ & 277 & 262 & 252 \\
\hline 6 & Cacao powder & 187 & 157 & 147 & 137 \\
\hline 7 & Wood and flax dust & 227 & 192 & 182 & 172 \\
\hline 8 & Activated carbon dust & $>300$ & 292 & 252 & 242 \\
\hline 9 & Wheat dust $\mathrm{n}^{\circ}$ 2 & 222 & 182 & 172 & 162 \\
\hline 10 & White wood dust & 232 & 197 & 182 & 172 \\
\hline 11 & Wood with asphalt dust & 222 & 187 & 172 & 162 \\
\hline 12 & Wheat dust $\mathrm{n}^{\circ} 3$ & 222 & 187 & 177 & 162 \\
\hline 13 & Persulphate powder & 132 & 102 & 97 & 82 \\
\hline 14 & Coal dust & 222 & 167 & 147 & 132 \\
\hline
\end{tabular}

Table 1: Results of self-ignition tests in heating ovens. 


\begin{tabular}{|c|c|c|c|c|c|}
\hline \multirow[b]{2}{*}{$\begin{array}{c}\text { Ref } \\
\text {. }\end{array}$} & \multirow[b]{2}{*}{ Samples } & \multirow{2}{*}{$\begin{array}{l}\text { Experiment } \\
\text { al results } \\
\left(\text { in }{ }^{\circ} \mathrm{C} \text { ) for } 5\right. \\
\mathrm{mm} \text { layers }\end{array}$} & \multicolumn{3}{|c|}{$\begin{array}{c}\text { Difference between prevision and experimental } \\
\text { values (in } \mathrm{K} \text { ) for } 5 \mathrm{~mm} \text { layers }\end{array}$} \\
\hline & & & $\begin{array}{c}\text { between } \alpha=1 \\
\text { and } \\
\text { experimental }\end{array}$ & $\begin{array}{l}\text { between } \alpha \\
\text { infinite and } \\
\text { experimental }\end{array}$ & $\begin{array}{l}\text { between } \alpha= \\
1 / 2 \text { and } \\
\text { experimental }\end{array}$ \\
\hline 1 & $\begin{array}{l}\text { Purifying station } \\
\text { mud dust }\end{array}$ & 273 & 9 & 37 & -9 \\
\hline 2 & Wheat dust $n^{\circ} 1$ & 300 & 80 & 133 & 46 \\
\hline 3 & Potatoes powder & 300 & -20 & -4 & -34 \\
\hline 4 & $\begin{array}{l}\text { Crushed waste } \\
\text { dust }\end{array}$ & 280 & 0 & 18 & -12 \\
\hline 5 & Zinc powder & 280 & 150 & 174 & 134 \\
\hline 6 & Cacao powder & 270 & 0 & 20 & -14 \\
\hline 7 & $\begin{array}{l}\text { Wood and flax } \\
\text { dust }\end{array}$ & 340 & -18 & 4 & -36 \\
\hline 8 & $\begin{array}{l}\text { Activated carbon } \\
\text { dust }\end{array}$ & $>450$ & \multicolumn{3}{|c|}{ Values not calculable } \\
\hline 9 & Wheat dust $n^{\circ} 2$ & $>450$ & \multicolumn{3}{|c|}{ Values not calculable } \\
\hline 10 & White wood dust & 333 & 5 & 31 & -15 \\
\hline 11 & $\begin{array}{l}\text { Wood with } \\
\text { asphalt dust }\end{array}$ & 333 & -7 & 19 & -27 \\
\hline 12 & Wheat dust $n^{\circ} 3$ & 297 & 25 & 51 & 13 \\
\hline 13 & $\begin{array}{l}\text { Persulphate } \\
\text { powder }\end{array}$ & 177 & 29 & 49 & 13 \\
\hline 14 & Coal dust & \multicolumn{4}{|c|}{ Experimental value not determined } \\
\hline
\end{tabular}

Table 2: Difference between theoretical and experimental self-ignition temperatures for $5 \mathrm{~mm}$ layers. Values are not calculable when experimental temperature is higher than $450{ }^{\circ} \mathrm{C}$. Coloration represent the accuracy of correlation obtained: the more darkly, the less accurate correlation. 


\begin{tabular}{|c|c|c|c|c|c|}
\hline \multirow[b]{2}{*}{ Ref } & \multirow[b]{2}{*}{ Samples } & \multirow{2}{*}{$\begin{array}{l}\text { Experimen } \\
\text { tal results } \\
\left(\text { in }{ }^{\circ} \mathrm{C} \text { ) for }\right. \\
12.5 \mathrm{~mm} \\
\text { layers }\end{array}$} & \multicolumn{3}{|c|}{$\begin{array}{c}\text { Difference between prevision and experimental } \\
\text { values (in K) for } 12.5 \mathrm{~mm} \text { layers }\end{array}$} \\
\hline & & & $\begin{array}{c}\text { between } \alpha=1 \\
\text { and } \\
\text { experimental }\end{array}$ & $\begin{array}{c}\text { between } \alpha \\
\text { infinite and } \\
\text { experimental }\end{array}$ & $\begin{array}{c}\text { between } \alpha=1 / 2 \\
\text { and } \\
\text { experimental }\end{array}$ \\
\hline 1 & $\begin{array}{l}\text { Purifying station } \\
\text { mud dust }\end{array}$ & \multicolumn{4}{|c|}{ Experimental value not determined } \\
\hline 2 & Wheat dust $n^{\circ} 1$ & \multicolumn{4}{|c|}{ Experimental value not determined } \\
\hline 3 & Potatoes powder & 280 & -38 & -22 & -48 \\
\hline 4 & $\begin{array}{l}\text { Crushed waste } \\
\text { dust }\end{array}$ & \multicolumn{4}{|c|}{ Experimental value not determined } \\
\hline 5 & Zinc powder & \multicolumn{4}{|c|}{ Experimental value not determined } \\
\hline 6 & Cacao powder & 260 & -34 & -16 & -46 \\
\hline 7 & $\begin{array}{l}\text { Wood and flax } \\
\text { dust }\end{array}$ & 320 & -46 & -26 & -60 \\
\hline 8 & $\begin{array}{l}\text { Activated carbon } \\
\text { dust }\end{array}$ & $>450$ & \multicolumn{3}{|c|}{ Values not calculable } \\
\hline 9 & Wheat dust $n^{\circ} 2$ & 390 & -122 & -98 & -136 \\
\hline 10 & White wood dust & \multicolumn{4}{|c|}{ Experimental value not determined } \\
\hline 11 & $\begin{array}{l}\text { Wood with } \\
\text { asphalt dust }\end{array}$ & \multicolumn{4}{|c|}{ Experimental value not determined } \\
\hline 12 & Wheat dust $n^{\circ} 3$ & \multicolumn{4}{|c|}{ Experimental value not determined } \\
\hline 13 & $\begin{array}{l}\text { Persulphate } \\
\text { powder }\end{array}$ & \multicolumn{4}{|c|}{ Experimental value not determined } \\
\hline 14 & Coal dust & \multicolumn{4}{|c|}{ Experimental value not determined } \\
\hline
\end{tabular}

Table 3: Difference between theoretical and experimental self-ignition temperatures for $12.5 \mathrm{~mm}$ layers. Values are not calculable when experimental temperature is higher than $450{ }^{\circ} \mathrm{C}$. Coloration represent the accuracy of correlation obtained: the more darkly, the less accurate correlation. 


\begin{tabular}{|c|c|c|c|c|c|}
\hline \multirow[b]{2}{*}{ Ref } & \multirow[b]{2}{*}{ Samples } & \multirow{2}{*}{$\begin{array}{l}\text { Experiment } \\
\text { al results } \\
\left(\text { in }{ }^{\circ} \mathrm{C} \text { ) for }\right. \\
15 \mathrm{~mm} \\
\text { layers }\end{array}$} & \multicolumn{3}{|c|}{$\begin{array}{c}\text { Difference between prevision and experimental } \\
\text { values (in } \mathrm{K} \text { ) for } 15 \mathrm{~mm} \text { layers }\end{array}$} \\
\hline & & & $\begin{array}{c}\text { between } \alpha=1 \\
\text { and } \\
\text { experimental }\end{array}$ & $\begin{array}{l}\text { between } \alpha \\
\text { infinite and } \\
\text { experimental }\end{array}$ & $\begin{array}{c}\text { between } \alpha=1 / 2 \\
\text { and } \\
\text { experimental }\end{array}$ \\
\hline 1 & $\begin{array}{l}\text { Purifying station } \\
\text { mud dust }\end{array}$ & 240 & -22 & 0 & -38 \\
\hline 2 & Wheat dust $n^{\circ} 1$ & 270 & -2 & 34 & -26 \\
\hline 3 & Potatoes powder & 270 & -34 & -20 & -44 \\
\hline 4 & $\begin{array}{l}\text { Crushed waste } \\
\text { dust }\end{array}$ & \multicolumn{4}{|c|}{ Experimental value not determined } \\
\hline 5 & Zinc powder & \multicolumn{4}{|c|}{ Experimental value not determined } \\
\hline 6 & Cacao powder & 240 & -20 & -4 & -34 \\
\hline 7 & $\begin{array}{l}\text { Wood and flax } \\
\text { dust }\end{array}$ & 300 & -34 & -14 & -48 \\
\hline 8 & $\begin{array}{l}\text { Activated carbon } \\
\text { dust }\end{array}$ & $>450$ & \multicolumn{3}{|c|}{ Values not calculable } \\
\hline 9 & Wheat dust $n^{\circ} 2$ & 290 & -30 & -10 & -46 \\
\hline 10 & White wood dust & \multicolumn{4}{|c|}{ Experimental value not determined } \\
\hline 11 & $\begin{array}{l}\text { Wood with asphalt } \\
\text { dust }\end{array}$ & \multicolumn{4}{|c|}{ Experimental value not determined } \\
\hline 12 & Wheat dust $n^{\circ} 3$ & \multicolumn{4}{|c|}{ Experimental value not determined } \\
\hline 13 & $\begin{array}{l}\text { Persulphate } \\
\text { powder }\end{array}$ & \multicolumn{4}{|c|}{ Experimental value not determined } \\
\hline 14 & Coal dust & 362 & -106 & -70 & -128 \\
\hline
\end{tabular}

Table 4: Difference between theoretical and experimental self-ignition temperatures for $15 \mathrm{~mm}$ layers. Values are not calculable when experimental temperature is higher than $450{ }^{\circ} \mathrm{C}$. Coloration represent the accuracy of correlation obtained: the more darkly, the less accurate correlation. 


\begin{tabular}{|c|c|c|c|c|c|c|c|}
\hline \multirow{3}{*}{ Ref } & \multirow{3}{*}{ Samples } & \multicolumn{6}{|c|}{$\begin{array}{l}\text { Difference between theoretical self-ignition } \\
\text { temperature values in K (relative difference in \%) }\end{array}$} \\
\hline & & \multicolumn{3}{|c|}{$\begin{array}{l}\text { Between } \alpha=1 \text { and } \alpha \\
\text { infinite }\end{array}$} & \multicolumn{3}{|c|}{$\begin{array}{c}\text { Between } \alpha=1 / 2 \text { and } \alpha \\
\text { infinite }\end{array}$} \\
\hline & & $5 \mathrm{~mm}$ & $\begin{array}{l}12,5 \\
\mathrm{~mm}\end{array}$ & $15 \mathrm{~mm}$ & $5 \mathrm{~mm}$ & $\begin{array}{l}12,5 \\
\mathrm{~mm}\end{array}$ & $\begin{array}{c}15 \\
\mathrm{~mm}\end{array}$ \\
\hline 1 & $\begin{array}{l}\text { Purifying station mud } \\
\text { dust }\end{array}$ & $\begin{array}{l}-28 \\
(-4.8)\end{array}$ & $\begin{array}{l}-22 \\
(-4.2)\end{array}$ & $\begin{array}{l}-22 \\
(-4.3)\end{array}$ & $\begin{array}{l}-46 \\
(-7.9)\end{array}$ & $\begin{array}{c}-38 \\
(-7.3)\end{array}$ & $\begin{array}{l}-38 \\
(-7.4)\end{array}$ \\
\hline 2 & Wheat dust $n^{\circ} 1$ & $\begin{array}{c}-53 \\
(-7.5) \\
\end{array}$ & $\begin{array}{c}-38 \\
(-6.4) \\
\end{array}$ & $\begin{array}{c}-36 \\
(-6.2)\end{array}$ & $\begin{array}{c}-87 \\
(-12.3) \\
\end{array}$ & $\begin{array}{c}-64 \\
(-10.8)\end{array}$ & $\begin{array}{c}-60 \\
(-10.4)\end{array}$ \\
\hline 3 & Potatoes powder & $\begin{array}{l}-16 \\
(-2.8)\end{array}$ & $\begin{array}{c}-16 \\
(-3.0)\end{array}$ & $\begin{array}{l}-14 \\
(-2.7)\end{array}$ & $\begin{array}{c}-30 \\
(-5.3)\end{array}$ & $\begin{array}{c}-26 \\
(-4.9)\end{array}$ & $\begin{array}{c}-24 \\
(-4.6)\end{array}$ \\
\hline 4 & Crushed waste dust & $\begin{array}{l}-18 \\
(-3.2)\end{array}$ & $\begin{array}{l}-14 \\
(-2.6)\end{array}$ & $\begin{array}{c}-16 \\
(-3.0)\end{array}$ & $\begin{array}{c}-30 \\
(-5.3) \\
\end{array}$ & $\begin{array}{l}-25 \\
(-4.7)\end{array}$ & $\begin{array}{c}-26 \\
(-5.0)\end{array}$ \\
\hline 5 & Zinc powder & $\begin{array}{c}-24 \\
(-3.3)\end{array}$ & $\begin{array}{l}-22 \\
(-3.3)\end{array}$ & $\begin{array}{c}-22 \\
(-3.3)\end{array}$ & $\begin{array}{c}-40 \\
(-5.5)\end{array}$ & $\begin{array}{c}-36 \\
(-5.4)\end{array}$ & $\begin{array}{c}-38 \\
(-5.7)\end{array}$ \\
\hline 6 & Cacao powder & $\begin{array}{l}-20 \\
(-3.6)\end{array}$ & $\begin{array}{c}-18 \\
(-3.5)\end{array}$ & $\begin{array}{c}-16 \\
(-3.1)\end{array}$ & $\begin{array}{c}-34 \\
(-6.0)\end{array}$ & $\begin{array}{c}-30 \\
(-5.8)\end{array}$ & $\begin{array}{l}-30 \\
(-5.9)\end{array}$ \\
\hline 7 & Wood and flax dust & $\begin{array}{c}-22 \\
(-3.6)\end{array}$ & $\begin{array}{c}-20 \\
(-3.5)\end{array}$ & $\begin{array}{c}-20 \\
(-3.6)\end{array}$ & $\begin{array}{l}-40 \\
(6.5)\end{array}$ & $\begin{array}{c}-34 \\
(-6.0)\end{array}$ & $\begin{array}{l}-34 \\
(-6.1)\end{array}$ \\
\hline 8 & Activated carbo & $\begin{array}{c}-104 \\
(-10.1) \\
\end{array}$ & $\begin{array}{c}-66 \\
(-8.1) \\
\end{array}$ & $\begin{array}{l}-62 \\
(-7.9) \\
\end{array}$ & $\begin{array}{c}-170 \\
(-16.5)\end{array}$ & $\begin{array}{c}-112 \\
(-13.7)\end{array}$ & $\begin{array}{c}-102 \\
(-13.0)\end{array}$ \\
\hline 9 & Wheat dust $n^{\circ} 2$ & $\begin{array}{l}-28 \\
(-4.5) \\
\end{array}$ & $\begin{array}{l}-24 \\
(-4.2) \\
\end{array}$ & $\begin{array}{c}-20 \\
(-3.6)\end{array}$ & $\begin{array}{c}-46 \\
(-7.4) \\
\end{array}$ & $\begin{array}{l}-38 \\
(-6.7)\end{array}$ & $\begin{array}{c}-36 \\
(-6.5)\end{array}$ \\
\hline 10 & White woc & $\begin{array}{c}-26 \\
(-4.1)\end{array}$ & $\begin{array}{c}-22 \\
(-3.8) \\
\end{array}$ & $\begin{array}{c}-20 \\
(-3.5)\end{array}$ & $\begin{array}{c}-46 \\
(7.2)\end{array}$ & $\begin{array}{c}-36 \\
(-6.2)\end{array}$ & $\begin{array}{c}-36 \\
(-6.3)\end{array}$ \\
\hline 11 & $\begin{array}{l}\text { Wood with asphalt } \\
\text { dust }\end{array}$ & $\begin{array}{c}-26 \\
(-4.2)\end{array}$ & $\begin{array}{c}-22 \\
(-3.9)\end{array}$ & $\begin{array}{l}-20 \\
(-3.6)\end{array}$ & $\begin{array}{c}-46 \\
(-7.4)\end{array}$ & $\begin{array}{l}-38 \\
(-6.7)\end{array}$ & $\begin{array}{c}-36 \\
(-6.5)\end{array}$ \\
\hline 12 & Wheat dust $n^{\circ} 3$ & $\begin{array}{c}-26 \\
(-4.2) \\
\end{array}$ & $\begin{array}{c}-20 \\
(-3.5) \\
\end{array}$ & $\begin{array}{c}-20 \\
(-3.6)\end{array}$ & $\begin{array}{c}-38 \\
(-6.1) \\
\end{array}$ & $\begin{array}{c}-36 \\
(-6.4)\end{array}$ & $\begin{array}{c}-36 \\
(-6.5)\end{array}$ \\
\hline 13 & Persulphate powder & $\begin{array}{c}-20 \\
(-4.0)\end{array}$ & $\begin{array}{c}-18 \\
(-4.0) \\
\end{array}$ & $\begin{array}{c}-18 \\
(-4.1)\end{array}$ & $\begin{array}{c}-36 \\
(-7.2) \\
\end{array}$ & $\begin{array}{c}-30 \\
(-6.7)\end{array}$ & $\begin{array}{c}-30 \\
(-6.8)\end{array}$ \\
\hline 14 & Coal dust & $\begin{array}{l}-52 \\
(-7.5) \\
\end{array}$ & $\begin{array}{l}-38 \\
(-6.5) \\
\end{array}$ & $\begin{array}{l}-36 \\
(6.4) \\
\end{array}$ & $\begin{array}{c}-84 \\
(-12.2) \\
\end{array}$ & $\begin{array}{c}-62 \\
(-10.6)\end{array}$ & $\begin{array}{c}-58 \\
(-10.3)\end{array}$ \\
\hline & \begin{tabular}{|lll} 
Average & (all values \\
included) & & \\
\end{tabular} & $\begin{array}{l}-33.1 \\
(-4.8)\end{array}$ & $\begin{array}{l}-25.7 \\
(-4.3)\end{array}$ & $\begin{array}{l}-24.4 \\
(-4.2)\end{array}$ & $\begin{array}{l}-55.2 \\
(-8.1)\end{array}$ & $\begin{array}{l}-43.2 \\
(-7.3)\end{array}$ & $\begin{array}{l}-41.7 \\
(-7.2)\end{array}$ \\
\hline & $\begin{array}{l}\text { Standard deviation } \\
\text { (all values included) }\end{array}$ & $\begin{array}{l}23.3 \\
(2.1)\end{array}$ & $\begin{array}{l}13.6 \\
(1.5)\end{array}$ & $\begin{array}{l}12.7 \\
(1.5)\end{array}$ & $\begin{array}{l}37.4 \\
(3.3)\end{array}$ & $\begin{array}{l}22.9 \\
(2.6)\end{array}$ & $\begin{array}{l}20.2 \\
(2.4)\end{array}$ \\
\hline
\end{tabular}

Table 5: Relative differences between theoretical self-ignition temperature values for several $\alpha$ values. 